\title{
AGAMA DAN KEHIDUPAN SOSIAL MASYARAKAT PENGRAJIN PERAHU DI TANAH LEMO KABUPATEN BULUKUMBA
}

\author{
ABD. KADIR AHMAD
}

\section{E K O L O G I}

Tanah Lemo adalah suatu kelurahan dalam wilayah Kecamatan Bontobahari Kabupaten Bulukumba terletak di bagian paling selatan jazirah Sulawesi Selatan. Berjarak $24 \mathrm{Km}$ dari kota Bulukumba dan $176 \mathrm{Km}$ dari Ujung Pandang, daerah ini termasuk kawasan pantai dengan elevasi $10 \mathrm{~m}$ di atas permukaan laut dan kemiringan rata-rata 2-15\%. Hujan turun rata-rata $2500 \mathrm{~mm}$ per tahun.

Luas wilayah Kelurahan Tanah Lemo 47.75 Km2, terdiri atas enam lingkungan, yaitu lingkungan Tanah Beru, Pasaraya, Batummesu, Benjala, Sapalohe dan Lemo-lemo. Jumlah penduduknyaa 11.385 jiwa, dengan komposisi 5475 laki-laki dan 5910 perempuan.1) Selain dari Tanah Lemo penduduk berasal dari berbagai daerah, seperti Selayar, Jeneponto, Gowa, Sinjai, Bone dan Bantaeng.

Selain menyerap migrasi dari luar (inmigration) Tanah Lemo juga memiliki penduduk asli yang sangat migratif. Sekitar $17 \%$ penduduknya kini bermigrasi ke Malaysia dan daerah lain di Indonesia. Hukum Revenstein tampaknya berlaku di tempat ini, bahwa turunnya jumlah penduduk di pedesaan sebagai akibat migrasi, akan diganti secara bertahap oleh migran dari daerah-daerah lain.2)

Selain didorong (push faktor) oleh semakin sempitnya daya dukung lahan migrasi keluar itu juga dimungkinkan oleh budaya migratif mereka yang tinggi. Dilihat dari daya dukung lahan, daerah ini memang terbilang "krisis". Secara umum, man-land-ratio, rata-rata penduduk memiliki lahan 0,45 ha; sedang familyland ratio sekitar 2 ha. Kondisi itu semakin kurang kondusis lagi dengan adanya 22,6\% termasuk lahan kritis sedangkan $42 \%$ lainnya kawasan hutan.

Seperti terlihat, tataguna lahan diarahkan pada berbagai peruntukan, meliputi perumahan 837 ha, persawahan 16 ha, perkebunan rakyat404 ha, tegalan 1653 ha, kawasan hutan 2165 ha, dan empang 33 ha.3) Karakteristik seperti itu menggolongkan daerah ini ke dalam tipe campuran dilihat dari tipologi kawasan pantai.4)

Keragaman pekerjaan penduduk menjadi indikator bagi tipologi itu. 2659 penduduk bekerja di bidang pertanian, nelayan 730, dagang 385, pertukangan/kerajinan (perahu) 721 orang, karyawan swasta 251 orang, peternak 243, dan pegawai negeri 156 orang.5) Berbeda dengan penduduk Desa Bira - Salah satu desa tetangga Tanah Lemo - yang bagian terbesar mengenal dan menggeluti kehidupan bahari (sebagai nelayan), orang-orang Tanah Lemo pada umumya bergerak dibidang pertanian, meski keduanya berada dalam lingkungan ekologi pantai. Karena itu kondisi lahan dapat menjadi sangat determinanbagi kelangsungan hidup mereka. Dapat dimengerti kalau banyak yang merantau; sedang yang pengrajin perahu kecil kemungkinannya untuk beralih propesi ke pertanian, begitu pula 
yang kebetulan bekerja sebagai nelayan.

Tingkat pendidikan penduduk menunjukkan lebih dari separoh telah pernah mengecap pendidikan mulai dari Sekolah Dasar $40 \%$, Sekolah Lanj utan Tingkat Pertama dan Tingkat atas masing-masing $8 \%$ dan Tingkat perguruan tinggi $1 \%$ (126 orang), selebihnya tergolong buta huruf dan tidak sekolah. Untuk memenuhi kebutuhan pendidikan disediakan sebelas buah Sekolah Dasar (6 SDN dan 5 SD Inpres), dan 1 buah sekolah agama (Ibtidaiyah).

Fasilitas prasarana dan sarana transportasi baik darat maupun laut mempermudah gerak penduduk daerah ini. Jalan beraspal poros Ujung Pandang-Bira melintasi Tanah Lemo, sehingga penduduk dapat melakukan perjalanan, dengan mobil atau motor, kapan saja mereka inginkan. Terhitung 38 buah mobil penumpang umum terdapat di Tanah Lemo, dan 118 buah motor (roda dua). Sarana angkutan laut tersedia 20 buah perahu milik masyarakat.

Yang kelihatan menonjol untuk ukuran pedesaan adalah pemilikan 113 buah televisi pribadi di samping 24 buah televisi umum bantuan pemerintah. Kedudukan sebagai ibukota Kecamatan (Bontobahari) membuat Tanah Lemo dapat mengikuti dinamikia pembangunan dan modernisasi yang datang melalui berbagai saluran; baik formal maupun informal.

\section{ANATOMI KERAJINAN PERAHU}

Tidak banyak suku bangsa Indonesia yang begitu intim kehidupannya dengan perahu dan laut seperti suku Makassar dan Bugis. Perahuperahu mereka sejak berabad-abad lalu sampai sekarang dengan setia mengarungi Nusantara, meramaikan jalur-jalur perdagangan dan pelayaran antar pulau di negeri ini. Di bandarbandar pelabuhan dan pusat-pusat nelayan tidak sukar menemukan pemukiman orangorang Makassar dan Bugis. Bahkan kolonikoloni mereka tidak hanya didapati di bandarbandar Nusantara, tetapi juga di kewasan Malaysia. Cambodia, Brunei, Filipina Selatan, dan di utara Australia(Berg, 1927, Sence, 1972, Tobing, 1961, dalam Pelly, 1986).

Prestasi kebaharian merupakan bahagian dari kejayaan masa lalu orang-orang Makassar dan Bugis. Dalam mobilitas horisontal mereka, perahu memegang peranan penting. Capaian mereka dalam teknologi keperahuan berkembang sedemikian rupa melampaui sistem teknologi transportasi darat.

Akan tetapi tidak semua komunitas orangorang Makassar dan Bugis yang menggeluti teknologi keperahuan. Entah mengapa, teknologi yang satu ini, untuk sebagian besarnya, hanya tumbuh dan berkembang di Kecamatan Bontobahari Kabupaten Bulukumba. Adalah Ara , salah satu desa dalam wilayah Bontobahari, yang populer, memiliki tradisi teknologi perakitan perahu sejak dulu. Konon dahulu kala tersebutlah sebuah perahu dari Cina (?) terdampar di pantai Ara. Orang Ara kemudian mengangkatnya ke darat dan mempelajari anatominya. Dari sinilah awal pengetahuan mereka tentang perakitan perahu. 1)

Sejarah Ara sebagai pusat perakitan perahu kemudian digeser oleh Tanah Lemo, tetangganya sendiri. Pertumbuhan Tanah Lemo yang didukung oleh berbagai fasilitas berkenaan dengan posisinya sebagai ibukota Kecamatan menjadi salah satu sebab dari kasus ini. Meski demikian, Ara bukan tidak melanjutkan tradisi itu sama sekali. SElain di daerah itu masih ada jumlah kecil usaha perakitan perahu. Orang-orang Ara juga tetap menggelutinya di daerah lain, misalnya di Tanah Lemo. Di tempat inilah mereka "bergabung" dengan orang-orang Lemo-lemo dan

No. 1 \& 2 Thn. I Juli / Desember 1990 
Tanah Beru. Dua terakhir termasuk dalam wilayah Tanah Lemo, yang juga memiliki tradisi keperahuan sejak lama.

Aktivitas kerajinan perakitan perahu di Tanah Lemo mencuatkan pemandangan yang khas. Sepanjang kurang lebih satu kilometer menyisir pantai sarat dengan deretan rumahrumah (landang) perakitan. Bahan-bahan baku dan perahu baik yang sedang maupun yang selesai dirakit memadati lokasi itu. Setiap landang-diatapi daun kelapa yang ditopang beberapa tiang dari bambu atau kayu yang dimiliki oleh satu keluarga sebagai unit usaha. Ukurannya bervariasi 'menurut besar kecilnya usaha. Landang dibangun tepat pada bahagian pantai yang tidak terkena air pasang guna memudahkan penurunan perahu ke laut.

Teknologi perakitan perahu terbilang masih "tradisional" terutama karena sistem pengetahuan yang mendukungnya masih melingkar pada penggunaan indigenious knowledge yang mereka warisi dari generasi ke generasi. Jauh sebelum adanya teknologi moderen seperti pemakaian lem (sistem leminasi) yang mulai diintrodusir sekarang, telah berkembang sistem teknologi tradisional. Peralatan, misalnya, mereka tetap memakai kampak, parang, pahat, ketam, gergaji tangan, bor, martil dan sebagainya, yang juga sering didapati pada teknologi pertukangan masyarakat Makassar dan Bugis pada umumnya.

Perakitan perahu dimulai dari pemotongan lunas (balok besar pada bahagian bawah/lantai perahu) sebagai organ utama, yang ditata sedemikian rupa sehingga kedua ujungnya melengkung sampai sekitar 20 derajat. Rangka dipasang setclah selesai pemasangan lantai/dinding. Papan-papan itu dipertautkan dengan memakai pasok (terbuat dari kayu ulin), yang dimasukkan ke dalam kedua sisinya yang sudah dilobangi dengan bor.
Untuk mencegah peresapan air melalui celahcelah papan itu mereka menyisipkan serbuk dari kulit pelepah enau (palapa inruk).

Berbeda dengan cerita awal pengetahuan orang Ara tentang bangunan perahu, kalangan panrita 3) di Tanah Lemo meyakini pengetahuan merakit perahu berawal dari nenek moyang mereka sendiri. Menurut cerita, bentuk perahu terinspirasi dari bentuk/bangun tubuh manusia. Lunasnya berbentuk tulang belakang manusia, rangkanya menyerupai tulang rusuk, lantainya daging, dan seterusnya. 4) Itulah sebabnya perahu yang mereka buat merupakan personifikasi dari dirinya sendiri.

Bahan baku perahu, umumnya, tersedia di daerah Tanah Lemo dan sekitarnya. Mereka memilih kayu tahan air dan zat garam. Kayu jenis itu terbilang langka kecuali naknasak (Mks) atau bittik (Bgs). Selain tumbuh secara alamiah, pohon ini ada yang sengaja dibudidayakan masyarakat. Dengan pembudidayaan setiap organ pohon yang sedang tumbuh dapat dimanipulasi ke dalam bentuk yang diinginkan, untuk kebutuhan tertentu, misalnya untu perahu atau kapal berukuran besar, bahan bakunya dipesan dari "Tenggara" (Raha).

Ketimbang sebelumnya, ada kecenderungan terjadinya degradasi pendapatan pada pengrajin. Salah satu faktor penyebabnya adalah dominannya pihak pemodal. Bahkan, ekstrimnya, pengrajin dapat dinafikan status kepengusahaannya dan lebih tepat disebut "buruh" 5) Namun demikian sulit untuk mengukur dan membandingkan tingkat income mereka dulu dengan sekarang perlu penelitian khusus. Sekedar perbandingan kasar, salah seorang pengrajin 6)hanya membandingkan nilai dari sebuah perahu. Dulu, pada generasi ayahnya, harga sebuah perahu dapat membiayai ongkos ke Tanah Suci (Mekah) suami istri, akan tetapi sekarang dibutuhkan minimal 5

No. 1 \& 2 Thn. I Juli / Desember 1990 
buah perahu untuk itu.

Harga sebuah perahu berukuran $3 \times 15 \mathrm{~m}$, dengan kapasitas muat $8-10$ ton dijual dengan nilai 2 - 3 juta rupiah. Sedangkan ukuran menengah, dapat dijual sampai 5 juta rupiah. Harga itu pun tidak tetap, tergantung dari kwalitasnya.

Dalam setahun pengrajin dapat menyelesaikan $5-7$ buah perahu, tergantung dari banyaknya pemesan. Semua pekerjaan dilakukan oleh anggota keluarga sendiri, kecuali jika ada pesanan mendesak mereka biasanya mengambil pekerja lain dengan upah 3000 rupiah per hari. Sistem pembagian hasil usaha bervariasi menurut kedudukan dan intensitas kerjanya. Karena sifatnya usaha keluarga, sistem distribusi itu sangat relatif. Prinsipnya, yang penting semua bisa hidup.7)

Upaya pengembangan usaha pengrajin bukan tidak dilakukan oleh Pemerintah. Di bidang teknis bimbingan dilakukan ke arah peningkatan "kualitas" produksi. Sistem leminasi, misalnya telah diintrodusir sejak tahun 1989. Salah seorang pengrajin mendapat penghargaan UPAKARTI dari Presiden berkat mengembangkan sistem baru itu. 8) Tetapi kebanyakan pengrajin belum mengikuti cara itu selain karena menganggap cara lama lebih safe, juga dinilainya lebih mahal.

Pengembangan di bidang permodalnan didekati melalui Koperasi Unit Desa (KUD) dan Koperasi Pengrajin Industri Rakyat (KOPINKRA). Kecuali kelompok-kelompok tertentu, keengganan pengrajin untuk ikut berkoperasi lebih banyak dilandasi oleh soal teknis dan prosedural. Karena mereka tidak memiliki tanah, satu-satunya barang yang dapat dijadikan jaminan adalah ruamh. Sedang bagi mereka adalah tabu untuk menjadikan rumah sebagai jaminan. Nilai rumah lebih dari sekedar nilai barang.
Sebagai sumber penghidupan utama posisi usaha perahu bagi mereka menempati dimensi "krisis". Mirip dengan petani pada umumnya, mereka sangat terikat oleh sifat "safety first" 9) Untuk itu berbagai persyaratan teknis, sosial dan moral akan mereka lakukan untuk menjamin keselamatannya. Meskipun untuk itu mereka siap hidup subsisten. Setiap gerak innovatif boleh jadi sangat sensitif, karenanya.

Sebagaimana umumnya orang Sulawesi Selatan, sikap konservatif mereka dalam bidang usaha perahu tidak menunjukkan hal yang sama dalam bidang transformatif. Posisi administratif dan geografis serta budaya migratif penduduk menjadi bahagian dari sebab-sebab yang mungkin mendorong kenyataan itu. Sebab lain adalah pengaruh pendidikan. Dalam Lingkuqgan Tanah Beru, dimana terdapat konsentrasi para pengrajin, $63 \%$ penduduknya telah tamat atau sedang menyelesaikan pendidikannya mulai dari SD $37 \%$, SLTP dan SLTA masing-masing 11,5 dan $12 \%$, dan Perguruan Tinggi 2,5\%. 10)

Ketegaran pengrajin menggeluti duanianya tampaknya tidak banyak terpengaruh dengan kondisi eksternal itu. Bahkan tradisi kerajian tersosialisasi secara otomatis kepada anakanaknya, melintasi batas-batas pendidikan dan status. Kesan akan seretnya tradisi ini pada suatu saat, akibat pergeseran dan transformasi sosial menjadi kurang aktual. Model jaring laba-bala 11) yang dianut pengrajin dalam mengembangkan usahanya mendapat konstribusi dari semakin banyaknya keluarga merekayang terdidik.

Secara struktural setiap usaha perakitan perahu keluarga terdiri atas komponen panrita, kepala tukang, tukang pelaksanaan dan pekerja. Kebijakan tertinggi ada pada panrita, sedang teknis operational ditangani oleh kepala tukang dan tukang yang dibantu para pekerja.

No. 1 \& 2 Thn. I Juli / Desember 1990 
Istilah punggawa-sawi 12) yang sering dipergunakan untuk mengidentifikasikan pola hubungan kerja masyarakat di Sulawesi Selatan relevan dengan watak hubungan kerja di bidang usaha perahu di Tanah Lemo.

\section{REFLEKSI KEHIDUPAN KEAGAMAAN}

Selain dua orang pendatang non-Islam (masing-masing beragama Protestan dan Hindu) semua penduduk Kelurahan Tanah Lemo beragama Islam. Tradisi keagaman (Islam) masyarakat di daerah ini terbentuk sejak awal masuknya Islam di kawasan itu (awal abad $17 \mathrm{M}$ ) yang dibawa dan dikembangkan oleh Abdul Jawab Khatib Bungsu. Dikenal kemudian dengan Datuk (Dato') Tiro, ulama ini - konon dari Minangkabau - mengajarkan Islam melalui jalur tasawuf, sesuai dengan karakteristik masya-rakat yang senang dengan ilmu magic. 1) Tradisi itu bagi masyarakat pengrajin adalah toddopuli (ultimate concern), sesuatu yang tidak dapat ditawar-tawar. Warna warisan penghayatan keagamaan yang menjunjung tinggi kekuatan batin (tasawuf) sangat intens di kalangan mereka. Bahkan mereka termasuk kelompok konservatif yang cenderung menentang paham "baru" dalam agama. Ini dapat dimcngerti, selain karena faktor geneologis, juga sangat berkaitan dengan "krisis"nya pekerjaan mereka selaku perakit perahu atau nelayan yang sewaktuwaktu harus berhadapan dengan kedahsyatan misteri bahari.

Dalam pelaksanaan syariat, kelompok pengrajin tcrgolong fanatik. Di Tanah Lemo, bahkan mereka menjadi pelopor dalam bidang keagamaan. Shalat lima kali sehari semalam dilaksanakan teratur. Begitu pula puasa (dalam bulan Ramadhan) dan kewajiban membayar zakat (fitra). Sedangkan ibadah haji telah ditunaikan lebih dari dua puluh (?) orang. 2)

Pengaturan jam kerja dari jam 8.00 sampai jam 17.00 tidak membuat pekerja terhalang beribadah (shalat). Jam 12-13 mereka istirahat dan kesempatan shalat dzuhur. Shalat dilakukan di tempat kerja ( di atas sebilah papan), di rumah, atau di mesjid (bagi mereka yang tinggal dekat mesjid) terutama pada malam hari. Ada 19 (sembilan belas) buah mesjid dalam kelurahan Tanah Lemo.

Puasa dilaksanakan oleh orang dewasa sampai anak-anak tanpa perlu meninggalkan pekerjaan rutin, meski dengan pengaturan waktu yang sedikit longgar. Pada malam hari mereka melaksanakan shalat tarwih (taraweh) dengan akhir bulan ramadhan. Dalam praktek ibadah mereka pada umumnya menganut pola "ahlussunnah". Sosialisasi ajaran agama dilakukan melalui jalur keluarga masyarakat dan sekolah.

Haji, bagi mereka, adalah suatu yang ideal, menjadi idaman sepanjang umur, meski itu tidak mudah. Seorang pengrajin, 3) misalnya, telah mewarisi tradisi haji dalam keuarganya sejak generasi kakeknya. Untuk melaksanakan ibadah haji tergantung dari pakkulle siagang pakkiyo (kemampuan dan panggilan tanah suci). Ada warga yang menunaikan haji pada usia muda karena syarat terpenuhi.

Masyarakat pengrajin terlibat secara total dalam kegiatan-kegiatan ritual dan seremonial keagamaan baik sendiri- sendiri maupun berkelompok. Apresiasi mereka terhadap upacara sering muncul melebihi porsinya dalam agama, misalnya dalam memperingati hari-hari besar Islam, upacara perkawinan, kematian, dan sebagainya. Bobot upacara itu bertumpu pada life cycle meski tidak semua unsurnya murni mengacu ke ajaran agama.

Upacara inisiasi, yang sarat nilai, atau disebut krisis peralihan, berlangsung mulai dari

No. 1 \& 2 Thn. I Juli / Desemoer 1990 
peristiwa kelahiran, pemberian nama (aqiqah), sunatan, perkawinan, sampai kepada kematian. Tanpa menyepelekan yang lain, dua terakhir menempati posisi amat krisis dalam siklus kehidupan mereka. Perkawinan, misalnya, menitik beratkan faktor keturunan dalam prinsip kafaah (sincerak). Kecuali kasuskasus tertentu, kesederajatan darah 4) sangat dominan dalam pemilihan calon suami/istri. Inheren dengan itu perkawinan lebih banyak berlangsung dalam lingkup kerabat (indogami)

Misteri alam kematian membuat upacara yang berkaitan dengan peristiwa itu dilakukan secara ketat. Selain melakukan apa-apa yang wajib dilakukan bagi seorang mayit (menurut ajaran Islam) praktek-praktek - kontroversial seperti talqin, upacara angngalle alio dan pengajian Al-Qur'an selama 7 atau 40 hari juga dilakukan oleh keluarganya.

Berbagai upacara juga mengiringi tahaptahap perakitan perahu, mulai dari pemotongan lunas (ammolong lunasa) sampai pada peluncuran perahu (appanaung). Upacara pemotongan lunas dipimpin oleh panrita atau seorang pemuka agama jika perahu yang akan dirakit cukup besar. Jika tidak, dilakukan oleh panrita sendiri. Dengan berbagai macam sajian makanan, upacara ammolong dilakukan dengan pembacaan-pembacaan barzanji.

Puncak upacara dilakukan menjelang peluncuran perahu, biasanya sehari sebelumnya. Masyarakat, secara spontan, mengambil bagian dalam upacara tersebut. Besar kecilnya upacara tergantung dari besar-kecilnya perahu yang akan diluncurkan. Terkait dengan itu juga jenis makanan yang disajikan :ayam, kambing, atau kerbau/sapi, dengan berbagai macam kue tradisional. Pemuka-pemuka agama setempat memainkan peran utama dalam upacara itu, terutama untuk membaca barzanji/sikkirik (dzikir). Pada saat peluncuran perahu, esok harinya, massa yang hadir pada upacara selamatan secara spontan ikut ambil bagian dalam pekerjaan berat tersebut.

Emosi keagamaan yang terjalin dalam kehidupan mereka bersama kekuatan adat, yang secara umum diidentifikasi sebagai pangngadakkan (Makassar), atau pangngaderreng (Bugis) 5) menyimpan faktor dinamika tersendiri dalam diri para pengrajin. Simbolsimbol keagamaan, sepertu rukun tigabelas (rokkong sampulo tallu) dan personifikasi perahu dengan wujud manusia sebagai ciptaan Allah diwujudkan konkritisasinya dalam perahu itu sendiri.6)

Bagi mereka tujuan hidup adalah abboya dallek hallalak, (mencari rezki yang halal). Sedangkan nilai kerja itu sendiri adalah berkah (barakka). Konkritisasi berkah terwujud dalam bentuk stabilitas usaha, kondisi ekonomi keluarga, kondisi kesehatan, perkembangan anak-anak dan keselamatan keluarga. Pada pihak lain terjelma pada keselamatan perahu itu sendiri dan kesejahteraan pemiliknya.

Agar berkah itu ada dalam suatu kerja, kalambusang (kejujuran) harus dipertahankan dan sikap hidup angngowa (rakus) harus dihindari. Pelanggaran terhadap aturan dapat berakibat fatal, misalnya perahu tidak dapat diluncurkan atau mengalami musibah pelayaran. Itulah sebabnya nilai kejujuran sangat dijunjung tinggi di daerah ini. Tidak pernah, misalnya terjadi pencurian bahan baku perahu.

Di satu sisi berkah juga dapat terwujud melalui sifat kedermawanan, dan menghindari sifat kikir. Para pengrajin melihat orang dermawan sebagai tau labbirik (mulia), labo (pemurah), dan tinggi pangngamaseang (pengasih). Sifat ini terwujud melalui kebiasaan memberi baik kepada kalangan keluarga sendiri, tetangga atau orang lain yang

No. 1 \& 2 Thn. I Juli / Desember 1990 
membutuhkan dan pada kepentingan agama. Kebiasaan menyumbang untuk pembangunan mesjid, misalnya, setelah sukses menjual hasil rakitan, merupakan bahagian- dari tradisi pengrajin. Bahkan ada pengrajin yang membangun mesjid seorang diri.

Hal lain yang berkaitan dengan berkah adalah kerajinan. Simbol kerajinan dikaitkan dengan apa yang mereka sebut attik songo (cucuran keringat). Suatu perbuatan paling tercelah adalah memakan hasil keringat (attik songo) orang lain.

\section{KESIMPULAN DAN SARAN}

\section{Kesimpulan}

Guna memenuhi kebutuhan warganya, masyarakat pengrajin perahu Tanah Lemo tumbuh sebagai suatu komunitas yang khas sesuai dengan watak ekologi pantai.

Faktor-faktor penunjang bagi fungsionalnya masyarakat tersebut antara lain adalah kemampuannya melakukan adaptasi dengan lingkungan, terutama dalam memanfaatkan dan memanipulasi sumberdaya alam pantai.

Selain itu faktor agama (Islam), sebagai sistem nilai yang dihayati masyarakat pengrajin turut menentukan integritas, dinamika, dan corak masyarakatnya. Dalam hal kerja, agama berperan memberikan motivasi, menentukan arah, dan menjadi landasan etika kerja para pengrajin.

\section{2. $S$ a $r$ a $n$}

Seirama dengan upaya pemanfaatan sumberdaya alam laut secara optimal, diperlukan pengembangan usaha perakitan perahu, baik melalui intensifikasi bimbingan teknis maupun melalui tunjangan permodalan yang memadai. Sejalan dengan itu pengembangan teknologi sosial perlu dilakukan tanpa meninggalkan unsur-unsur tradisionalitasnya.

Perlu bimbingan khusus tentang pelaksanaan kewajiban zakat harta bagi hasil usaha perakitan. 


\section{CATATAN KAKI}

i.

1.Sumber data: Kantor Kelurahan Tanah Lemo

2. H.S. Sunarto, Dinamika Migrasi di Indonesia, Lembaga Kependudukan Universitas Gaja Mada, 1987.

3. Sumber data : Kantor Kelurahan Tanah Lemo.

4. M. Arifin Sallatang, Desa pantai di Sulawesi Selatan dan Strategi Pengembangannya, dalam jurnal penelitian sosial Vol. I - II tahun 1976 - 1977. Menurut Arifin, ditemukan empat tipe Desa pantai, yaitu tipe (1) tanaman bahan makanan, (2) tanaman industri, (3) nelayan dan empang, (4) perdagangan dan pengangkutan.

5. Sumber data : Kantor Kelurahan Tanah Lemo.

n.

1. Hasil wawancara dengan Drs. Umar Tjalo, Camat Bontobahari.

2. Akumulasi pengctahuan tradisional penduduk lokal.

3. Panrita adalah seorang yang memiliki keahlian khusus dalam pcmbuatan perahu.

4. Hasil wawancara dengan haji jafar (60 tahun), panrita.

5. Hasil wawancara dengan Drs. Umar Tjalo.

6. Haji Jafar, yang mendapat kepercayaan merakit perahu Hati Marege, perahu yang khusus dibuat untuk melakukan ekspedisi tradisional ke Darwin Australia tahun 1988.

7. Hasil wawancara dengan Abdul Latif (70 tahun), panrita.
8. Hasil wawancara dengan Drs. Umar Tjalo.

9. James C. Scott, Moral Ekonomi Petani, LP3ES, 1976.

10. Sumber data : Kantor Kelurahan Tanah Lemo.

11. jaring Laba-laba adalah model manajemen tradisional pengusaha Sulawesi yang bercirikan usaha keluarga. Lihat Mattulada, Manajemen tradisional dalam Kalangan Bugis Makassar, dalam Dinamika Bugis Makassar, PLPIISYIIS, 1986

12. Punggawa - Sawi adalah pola umum organisasi usaha Bugis-Makassar, yang menyerupai hubungan Patron - Client. Lihat Heddy Shri Ahimsa Putra, Minawang, Gaja Mada University Press, 1988.

III.

1. Abu Hamid, Sistem Pendidikan Madrasah dan Pesanteren di Sulawesi Selatan, dalam Taufik Abdullah, Agama dan Perubahan SOsial, 1983.

2. Hasil Wawancara dengan Abdul Azis Lopo, Lurah Tanah Lemo.

3. Hasil wawancara dengan Haji jafar.

4. Kesederajatan berkaitan dengan strarifikasi sosial masyarakat Bontobahari tcrdiri atas (1) Pattola. (2) Barrisi, (3) Tabbalak, (4) Ata. Lihat Jufrina Rizal, Kehidupan wanita Bira, 1978.

5. Pangngadakkang adalah sistem norma dan aturan adat yang terdiri atas ada' bicara, wari', rapang, dan sara'. Lihat Mattulada, Latoa, 1985

6. Hasil wawancara dengan Haji Jafar. 
membutuhkan dan pada kepentingan agama. Kebiasaan menyumbang untuk pembangunan mesjid, misalnya, setelah sukses menjual hasil rakitan, merupakan bahagian- dari tradisi pengrajin. Bahkan ada pengrajin yang membangun mesjid seorang diri.

Hal lain yang berkaitan dengan berkah adalah kerajinan. Simbol kerajinan dikaitkan dengan apa yang mereka sebut attik songo (cucuran keringat). Suatu perbuatan paling tercelah adalah memakan hasil keringat (attik songo) orang lain.

\section{KESIMPULAN DAN SARAN}

\section{Kesimpulan}

Guna memenuhi kebutuhan warganya, masyarakat pengrajin perahu Tanah Lemo tumbuh sebagai suatu komunitas yang khas sesuai dengan watak ekologi pantai.

Faktor-faktor penunjang bagi fungsionalnya masyarakat tersebut antara lain adalah kemampuannya melakukan adaptasi dengan lingkungan, terutama dalam memanfaatkan dan memanipulasi sumberdaya alam pantai.

Selain itu faktor agama (Islam), sebagai sistem nilai yang dihayati masyarakat pengrajin turut menentukan integritas, dinamika, dan corak masyarakatnya. Dalam hal kerja, agama berperan memberikan motivasi, menentukan arah, dan menjadi landasan etika kerja para pengrajin.

\section{2. $\mathrm{S}$ a $\mathbf{r}$ a $\mathrm{n}$}

Seirama dengan upaya pemanfaatan sumberdaya alam laut secara optimal, diperlukan pengembangan usaha perakitan perahu, baik melalui intensifikasi bimbingan teknis maupun melalui tunjangan permodalan yang memadai. Sejalan dengan itu pengembangan teknologi sosial perlu dilakukan tanpa meninggalkan unsur-unsur tradisionalitasnya.

Perlu bimbingan khusus tentang pelaksanaan kewajiban zakat harta bagi hasil usaha perakitan. 